
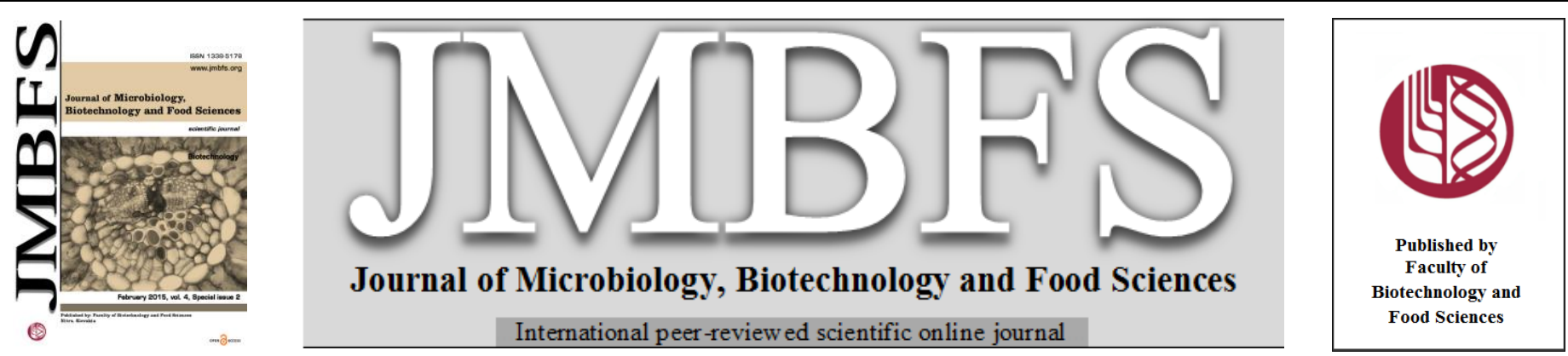

\title{
THE CHANGES IN ALBUMIN CONCENTRATION AFTER ACRYLAMIDE EXPOSURE IN MICE BRAIN STRUCTURES
}

\author{
Marta Kopańska ${ }^{1}$, Patrycja Zagata ${ }^{2}$, Marta Głogowska ${ }^{3}$, Grzegorz Formicki $^{1}$
}

\begin{abstract}
Address(es): MSc. Marta Kopańska
${ }^{1}$ Pedagogical University of Cracow, Faculty of Geography and Biology, Institute of Biology, Department of Animal Physiology and Toxicology, Podbrzezie 3, 31-054 Cracow, Poland, +48126626720 .

${ }^{2}$ Pedagogical University of Cracow, Faculty of Geography and Biology, Institute of Biology, Department of Plant Physiology, Podbrzezie 3, 31-054, Cracow, Poland, +48 126626720

${ }^{3}$ Pedagogical University of Cracow, Faculty of Geography and Biology, Institute of Biology, Department of Vertebrate Zoology and Human Biology, Podbrzezie 3 , 31-054, Cracow, Poland, +48 126626720 .
\end{abstract}

*Corresponding author: martakopanska@ poczta.onet.pl

doi: 10.15414/jmbfs.2015.4.special2.54-56

\section{ARTICLE INFO}

Received 10. 12. 2014

Revised 16. 12. 2014

Accepted 20.1.2015

Published 2. 2. 2015

Regular article

OPEN $\partial_{\text {ACCESS }}$

\section{ABSTRACT}

Acrylamide is a chemical compound that typically forms in starchy food products during high-temperature cooking, including frying, baking and roasting. Acrylamide is a known lethal neurotoxin. Albumin is an important molecule under physiological and pathophysiological conditions. It has multiple effects, including regulation of osmotic pressure; carrier of poorly water soluble molecules, such as hormones, cholesterol, calcium, iron, bilirubin, free fatty acids, and drugs; and anti-oxidant properties. The aim of work was to estimate the content of albumins after acrylamide in the: right hemisphere, left hemisphere, cerebellum and brain stem. Although no high significant changes after each time, there occured influence of acrylamide albumins concentration. Significantly decreased content of albumins occures in oxidative stress.

Keywords: Albumins, brain, acrylamide, oxidative stress

\section{INTRODUCTION}

Acrylamide is an organic compound $\mathrm{H} 2 \mathrm{C}=\mathrm{CH}-\mathrm{CONH} 2$ which occurs via acrylonitryle hydrolysis. Particularly high concentration of acrylamide is formed during thermal processing of food products containing high concentrations of hydrocarbons. It is a product of Millard reaction between the amino acid asparagine and the carbohydrate. The visible effect of the Maillard reaction is a browning of the product during baking . Therefore, acrylamide is present in many foods - bread , coffee, breakfast cereals , baked meat, but its highest concentration is in starchy vegetable, chips, French fries, cakes and biscuits ( Mustafa and others,2008) . International Agency for research on Cancer classified acrylamide as probable human carcinogen (Chico et al., 2006; Mustafa et al., 2008). Carcinogenic properties are shown by acrylamide monomer exclusively. Polimeric forms are non-toxic (Rice, 2005). Animal model studies indicated significant correlation between the concetntarion of acrylamide in food and number of acrylamide adducts with haemoglobin (Szczerbina et al., 2008). Acrylamide is partially removed from the organism with urine. Metabolism of acrylamide is complicate. Its biotransformation occurs in liver, where acrylamide is conversed to glycidamide (more reactive derivative of epoxide) via cytochrome P450. Both acrylamide and glycidamide enter the conjugation reaction with glutathione. N-Acetyl-S-(3-amino-3-oxypropyl) cysteine occurs as product of direct conjugation of acrylamide and glutathione. Glycidamide takes part in two alternative pathways i.e. conjugation with glutahione catalysed by glutathione S-transferase leading to formation of $\mathrm{N}$ Acetyl-S-(2-carb-moylo-2-hydroxy-ethyl)cysteine or N-Acetyl-S-(3-amino-2hydroxy-3-oksopropyl) cysteine (Szczerbina et. al., 2008). The second pathway is related with enzymatic hydrolysis to dihydroxypropane amide. Both glicidamide and acrylamide show neurotoxic properties on the other hand, glicidamide has grater affinity to DNA than acrylamide. Glicidamide genotoxicity is related to its conjugates with DNA which lead to chromosomal injuries (Żyżelewicz et. al., 2010). Numerous reports indicate the involvement of free radicals in acrylamide cytotoxicity (Bednarska, 2011).

Albumin is the major plasma protein. It has many important functions in the human body, including responsible for the maintenance of normal blood pressure, antioxidant balance, antithrombotic activity and they exhibit as a reservoir of amino acids (Miller, 2001). The most important role of albumin is an ability to transport endogenous and exogenous ligands such as fatty acids bilirubin , some hormones and toxins, drugs , and ions to target tissues. Albumin is used as a prognostic marker in many diseases, especially where we observed decrease in its concentration associated with impaired synthesis with increased demand (cancer), or loss from the body (diabetes, kidney disease , burns) (Miller , 2001). In addition to quantitative changes, the albumin is influenced by the structural modification of various factors such as oxidative stress. There are variety of physical and chemical changes in the structure of albumin (oxidation of amino acid residues or cross-linking between amino acids). These changes lead to disturbances in their biological activity and pharmacokinetic properties , including to reduce the binding capacity of transition metal ions ( cobalt, copper and nickel ) (Kordecka et al, 2008).

Taking into account the high consumption of acrylamide in human daily diet, its high potency to induce redox imbalance and its neurotoxic properties we aimed to study acrylamide influence on albumin concentration in chosen brain structures of mice i.e. the right hemisphere, the left hemisphere, cerebellum and brain stem.

\section{MATERIALS AND METHODS}

The measurements were performed after 24, 48 and 168 hours after acrylamide injection. The research was conducted on SWISS mice 8 week old, weight $26 \mathrm{~g}$. The animals were segregated into 6 experimental and 3 control groups. Animals from experimental groups were injected intraperitoneally with ACR doses of 20 $\mathrm{mg} / \mathrm{kg}$ and $40 \mathrm{mg} / \mathrm{kg} \mathrm{ACR}$ at $7 \mathrm{am}$ (Tab. 1). Control group of mice were injected with physiological saline 3 times a week. ACR was dissolved in $0.9 \%$ saline and administered at dose of $3 \mathrm{ml} / \mathrm{kg}$. Each group consisted of 6 animals. Total number of animals was 54. Animals were fed with standard diet and grown in 12/12 light photoperiod. 24 hours after each injection series i.e. after 24,48 and $168 \mathrm{~h}$ of the experiment mice were anaesthetized and the structures of the brain trunk, cerebellum and both hemispheres were dissected. ALB concentration was measured using BioLa Test (PLIVA-Lachema, Brno, Czech Republic) commercial kit. The measurement was based on the reaction between albumin and Bromocresol Green (BCG) at acid $\mathrm{pH}$ forming a complex, which was easy to detect photometrically at $578 \mathrm{~nm}$. 
Table. 1 The experimental design

\begin{tabular}{|c|c|c|c|c|c|}
\hline GROUP & DOSE OF ACR & $\begin{array}{c}\text { NUMBER AND TIME OF } \\
\text { INJECTIONS }\end{array}$ & TOTALDOSE & $\begin{array}{c}\text { TIME OF } \\
\text { DISSECTION }\end{array}$ & $\begin{array}{c}\text { NUMBER OF } \\
\text { ANIMALS }\end{array}$ \\
\hline Control I & $3 \mathrm{ml}(0,9 \% \mathrm{NaCl})$ & $1-1$ st hour & & After $24 \mathrm{~h}$ & 6 \\
\hline $24 \mathrm{~A}$ & $20 \mathrm{mg} / \mathrm{kg}$ & $1-1$ st hour & $20 \mathrm{mg} / \mathrm{kg}$ & After 24 & 6 \\
\hline $24 \mathrm{~B}$ & $40 \mathrm{mg} / \mathrm{kg}$ & $1-1$ st hour & $40 \mathrm{mg} / \mathrm{kg}$ & After 24 & 6 \\
\hline Control II & $3 \mathrm{ml}(0,9 \% \mathrm{NaCl})$ & $1-1$ st and 24th hour & & After $48 \mathrm{~h}$ & 6 \\
\hline $48 \mathrm{~A}$ & $20 \mathrm{mg} / \mathrm{kg}$ & $2-1$ st and 24th hour & $40 \mathrm{mg} / \mathrm{kg}$ & After $48 \mathrm{~h}$ & 6 \\
\hline $48 \mathrm{~B}$ & $40 \mathrm{mg} / \mathrm{kg}$ & $2-1$ st and 24th hour & $80 \mathrm{mg} / \mathrm{kg}$ & After $48 \mathrm{~h}$ & 6 \\
\hline Control III & $3 \mathrm{ml}(0,9 \% \mathrm{NaCl})$ & $3-1^{\text {st }}, 24^{\text {th }}$, and $144^{\text {th }}$ hour & & After $168 \mathrm{~h}$ & 6 \\
\hline $168 \mathrm{~A}$ & $20 \mathrm{mg} / \mathrm{kg}$ & $3-1^{\text {st }}, 24^{\text {th }}$, and $144^{\text {th }}$ hour & $60 \mathrm{mg} / \mathrm{kg}$ & After $168 \mathrm{~h}$ & 6 \\
\hline $168 \mathrm{~B}$ & $40 \mathrm{mg} / \mathrm{kg}$ & $3-1^{\text {st }}, 24^{\text {th }}$, and $144^{\text {th }}$ hour & $120 \mathrm{mg} / \mathrm{kg}$ & After $168 \mathrm{~h}$ & 6 \\
\hline
\end{tabular}

\section{Statistical analysis}

Obtained data were statistically analyzed using PC program GraphPad Prism 3.02 (GraphPad Software Incorporated, San Diego, California, USA). Descriptive statistical characteristics (mean, minimum, maximum, standard deviation and coefficient of variation) were evaluated. One-way analysis of variance (ANOVA) and the Dunnett's multiple comparison test were used for statistical evaluations. The level of significance was set at $\quad * * *(P<0.001) ; * *(P<0.01)$ and $*$ $(P<0.05)$.

\section{RESULTS}

Data of the toxic effects of intraperitoneal acrylamide exposure on the cerebral albumin concentration are presented on the Figures 1-4. As shown in Table 2-5, administration of ACR caused non-significant and significant $[(\mathrm{p} \leq 0,05)$ $(\mathrm{p} \leq 0,01),(\mathrm{p} \leq 0,001)]$ decrease in albumin content of treated groups of mice as compared to their corresponding controls in chosen brain structures.

Table 2 Effect on the Albumin content after intraperationeal administration of ACR (20mg/kg, 40mg/kg b.wt) in the right hemisphere

\begin{tabular}{cccc}
\multicolumn{4}{c}{ RIGHT HEMISPHERE } \\
\hline Group & \multicolumn{4}{c}{$\mathbf{4 8 H}$} & $\mathbf{7 2 H}$ & 8D \\
\hline Control & $14,525 \pm 0,748$ & $12,086 \pm 1,025$ & $19,405 \pm 1,220$ \\
\hline $20 \mathrm{mg} / \mathrm{kg}$ & $16,255 \pm 2,445$ & $8,689 \pm 0,688$ & $11,948 \pm 0,819^{* * *}$ \\
\hline $40 \mathrm{mg} / \mathrm{kg}$ & $12,875 \pm 0,572$ & $9,750 \pm 1,240$ & $9,397 \pm 0,551^{* * *}$ \\
\hline Values are given as mean \pm SEM for 6 mice of each group; ${ }^{*}$, significant $(\mathrm{p} \leq 0,05),{ }^{* *}(\mathrm{p} \leq 0,01),{ }^{* * *}(\mathrm{p} \leq 0,001)$ as compared with the control group
\end{tabular}

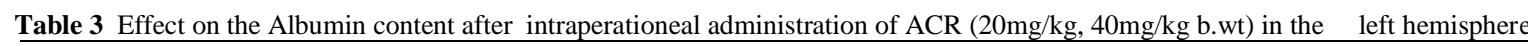

\begin{tabular}{|c|c|c|c|}
\hline \multirow{2}{*}{\multicolumn{4}{|c|}{ LEF T HEVISTHEKE }} \\
\hline & & & \\
\hline Control & $16,775 \pm 1,349$ & $13,336 \pm 0,904$ & $18,655 \pm 0,383$ \\
\hline $20 \mathrm{mg} / \mathrm{kg}$ & $15,505 \pm 2,087$ & $9,689 \pm 0,688$ & $11,698 \pm 0,693^{* * *}$ \\
\hline $40 \mathrm{mg} / \mathrm{kg}$ & $11,875 \pm 0,572$ & $11,000 \pm 1,366$ & $8,147 \pm 0,734 * * *$ \\
\hline
\end{tabular}

Values are given as mean \pm SEM for 6 mice of each group; ${ }^{*}$,significant $(\mathrm{p} \leq 0,05),{ }^{* *}(\mathrm{p} \leq 0,01),{ }^{* * *}(\mathrm{p} \leq 0,001)$ as compared with the control group

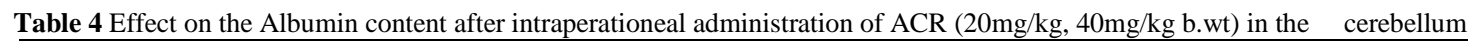

\begin{tabular}{cccc}
\hline \multicolumn{5}{c}{ CEREBELLUM } & \multicolumn{1}{c}{$\mathbf{7 2 H}$} \\
\hline Group & \multicolumn{4}{c}{$\mathbf{4 8 H}$} & \multicolumn{1}{c}{ 8D } \\
\hline Control & $15,455 \pm 0,807$ & $13,176 \pm 1,281$ & $11,704 \pm 2,682$ \\
\hline $20 \mathrm{mg} / \mathrm{kg}$ & $13,500 \pm 0,656$ & $11,017 \pm 1,325$ & $7,886 \pm 1,687$ \\
\hline $40 \mathrm{mg} / \mathrm{kg}$ & $12,385 \pm 0,308^{*}$ & $6,758 \pm 0,516^{* *}$ & $7,531 \pm 1,315$ \\
\hline
\end{tabular}

Values are given as mean \pm SEM for 6 mice of each group; ${ }^{*}$,significant $(\mathrm{p} \leq 0,05),{ }^{* *}(\mathrm{p} \leq 0,01),{ }^{* * *}(\mathrm{p} \leq 0,001)$ as compared with the control group

Table 5 Effect on the Albumin content after intraperationeal administration of ACR $(20 \mathrm{mg} / \mathrm{kg}, 40 \mathrm{mg} / \mathrm{kg}$ b.wt) in the brain stem

\begin{tabular}{|c|c|c|c|}
\hline \multicolumn{4}{|c|}{ BRAIN STEM } \\
\hline Group & $48 \mathrm{H}$ & 72 & 8D \\
\hline Control & $20,400 \pm 2,181$ & $11,916 \pm 1,466$ & $20,415 \pm 3,283$ \\
\hline $20 \mathrm{mg} / \mathrm{kg}$ & $12,735 \pm 0,686^{*}$ & $13,840 \pm 1,274$ & $16,179 \pm 2,430$ \\
\hline $40 \mathrm{mg} / \mathrm{kg}$ & $12,585 \pm 0,310^{*}$ & $9,956 \pm 0,712$ & $11,259 \pm 1,752$ \\
\hline
\end{tabular}

Acrylamide administration induced decrease in albumin content in tested brain structures. Compared to the control groups, ACR administration induced significant decrease of Albumin content in right hemisphere (Fig. 1) after 8 days $(20 \mathrm{mg} / \mathrm{kg}, \quad \mathrm{p}<0,001 ; 40 \mathrm{mg} / \mathrm{kg}, \mathrm{p}<0,001)$. In the left hemisphere (Fig. 2), significant decrease of Albumin concentration occurred after 8 days $(20 \mathrm{mg} / \mathrm{kg}$, $\mathrm{p}<0,001 ; 40 \mathrm{mg} / \mathrm{kg}, \mathrm{p}<0,001)$. Moreover, a statistically significant depletion in Albumin concentration in cerebellum were after 48 hours $(40 \mathrm{mg} / \mathrm{kg}, \mathrm{p}=0,013)$ and after 72 hours $(40 \mathrm{mg} / \mathrm{kg}, \mathrm{p}=0,005)$. Acrylamide-exposed SWISS mice exhibited significant $(20 \mathrm{mg} / \mathrm{kg}$ and $40 \mathrm{mg} / \mathrm{kg} ; \mathrm{p}<0,05)$ decrease of Albumin in brain stem after 48 hours The rest changes were also with decreaced tendency, although there were insignificant.

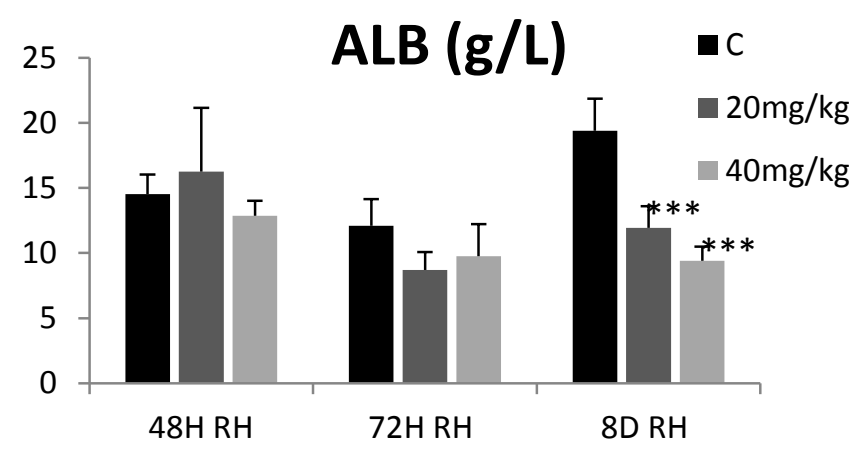

Figure 1 The concentration of Albumin in the right hemisphere after intraperitoneal injection of acrylamide in two different doses $20 \mathrm{i} 40 \mathrm{mg} / \mathrm{kg}$ b.w. 


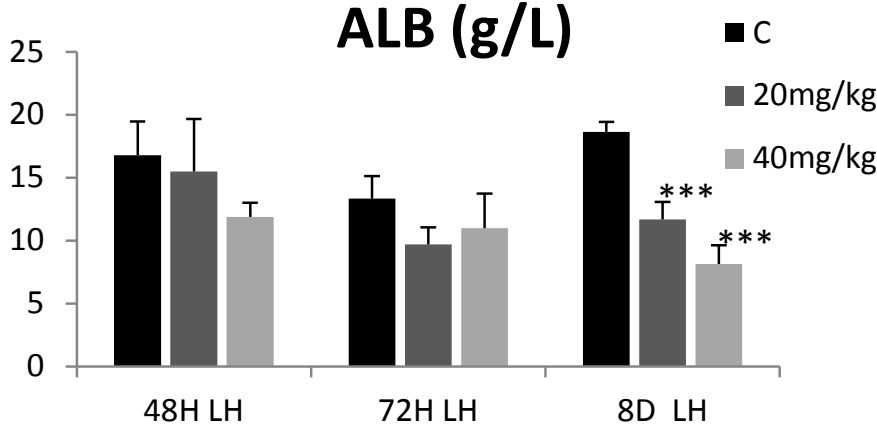

Figure 2 The concentration of Albumin in the left hemisphere after intraperitoneal injection of acrylamide in two different doses $20 \mathrm{i} 40 \mathrm{mg} / \mathrm{kg} \mathrm{b.w}$.

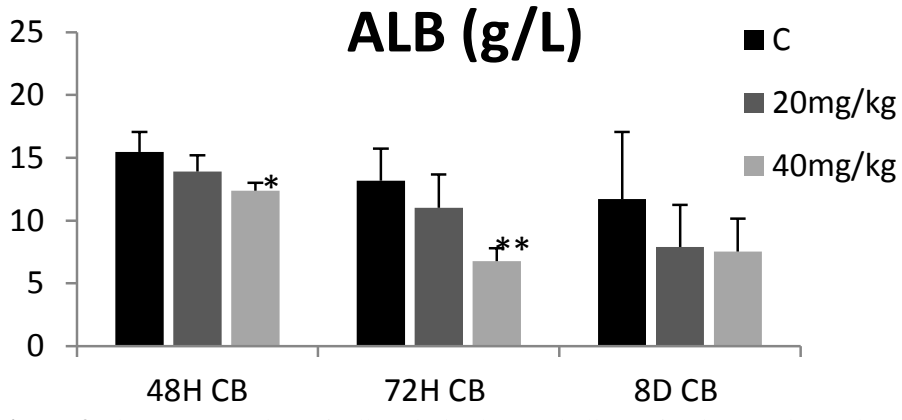

Figure 3 The concentration of Albumin in the cerebellum after intraperitoneal injection of acrylamide in two different doses $20 \mathrm{i} 40 \mathrm{mg} / \mathrm{kg}$ b.w.

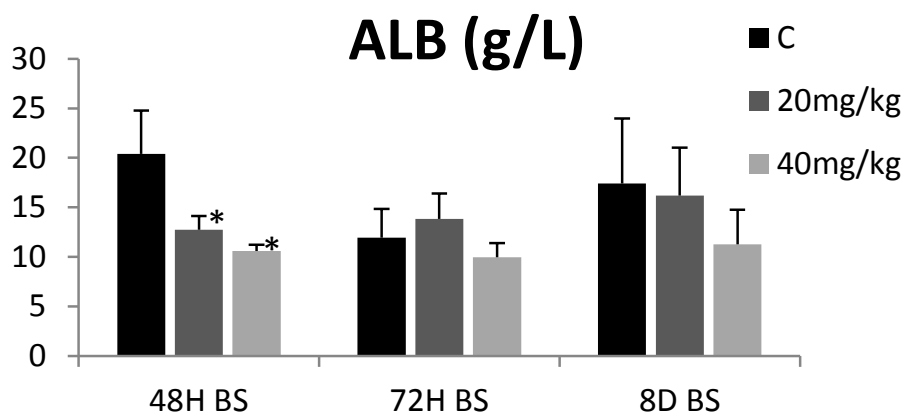

Figure 4 The concentration of Albumin in the brain stem after intraperitoneal injection of acrylamide in two different doses $20 \mathrm{i} 40 \mathrm{mg} / \mathrm{kg} \mathrm{b} . \mathrm{w}$.

\section{DISCUSSION}

Acrylamide is a very reactive organic compound including a conjugated double bond and an amid fragment. High chemical reactivity of acrylamide is an effect of occurrence of a multiple bond with electrophilic characteristics. The double bond plays the role of an electrophilic center, which is sensitive to attacks from amino acids' amine $\left(-\mathrm{NH}_{2}\right)$ or sulfhydryl $(-\mathrm{SH})$ groups. From previous researches we know that ACR has a carcinogenic influence on human health (IARC, 1994). According to Prof. Dale Hattis from American Clark university, acrylamide is a cause of a dozen or so thousands of cases of contracting cancer every year. There are some specific places in organisms which are very susceptible to oxidative damages (Bandyopadhyay et al., 1999). In accordance with the studies of Sharma and Jain (2008) and El-Bohi et al. (2011), the present study showed that ACR reduced the level of albumins. ACR molecule's high reactivity is due to occurrence of conjugated double bond and the amine group. The amine group can conjugate with $-\mathrm{SH}$ and a- $\mathrm{NH}_{2}$ groups of free amino acids. This could be the cause of decreased tendency in concentrations of albumins in different brain structures. Albumin is a protein with strong ant oxidative activity. It can easily bind with vitamins, mineral salts, unsaturated fatty acids and hormones, which transport the albumin in our organism. Furthermore, the albumin carries metabolism products and toxic substances from cells to the liver, where these substances take part in processes of decomposition and detoxification. Human organs like liver, brain, entrails or kidneys work properly, when the albumin level is high enough and suitable proportions between the water amount in blood and water amount in tissues liquids are maintained. Unsettled albumin level can be the cause of disturbance of many processes connected with filtration and water osmosis through blood vessels. Thus, the low level of albumin can disturb processes of urine, extracellular liquids and lymph production (Peteres et al. 1996). People with a low level of albumin in blood serum are characterized of a high mortality level. Increased level of albumin is a cause of dehydration. Whereas the cause of decrease of albumin level can disturb various processes such as albumin synthesis, absorption or malnutrition and illnesses of liver, alimentary canal, nephrotic syndrome, bleedings, sepsis, increased albumin catabolism, injuries, high body temperature, cancers or hyperhydration (Kordecka et al., 2008).

Our studies indicate that acrylamide is highly toxic and has a harmful effect on brain, which is confirmed by Sheng et al. (2009), who stated that human brain is particularly sensitive to the influence of acrylamide. Our work has revealed that acrylamide determines albumin level in certain brain structures. We observed decreasing tendency of albumin concentration, especially after a longer duration of the experiment. Observed fluctuations can be due to organism's attempt to adapt to changing conditions. The most important region of ions binding by albumin is N-terminal compound's fragment, including a sequence of four amino acids: asparagine-alanine-histidine-lysine (Asp-Ala-His-Lys) (Anraku et al., 2001). The N-terminal fragment is very sensitive to damages, especially when additionally it is exposed to the influence of free radicals, produced during the oxidative stress, acidosis or decreased oxygen tension (Peteres et al., 1996). Decrease of albumin level can be due to the influence of free radicals produced during the oxidative stress induced by neurotoxin acrylamide.

\section{CONCLUSION}

The results of present study indicated that acrylamide has toxic effects which is reflected in decreased albimins level in right and left hemisphere, cerebellum and brain stem.

\section{REFERENCES}

ANRAKU M, YAMASAKI K, MARUYAMA T, KRAGH-HANSEN U, OTAGIRI M., 2001. Effect of oxidative stress on the structure and function of human serum albumin. Pharm Res; 18: 632-639. http://dx.doi.org/10.1023/A:1011029226072

CHICO GALDO V.,MASSART C., JIN L., VANVOOREN V., CAILLETFAUQUET P., ANDRY G., LOTHAIRE P., DEQUANTER D., FRIEDMAN M. VAN SANDE J., 2006 Acrylamide an in vitro thyroid carcinogenic agent, induces DNA damage in rat thyroid cell lines and primary cultures, Molecular $\begin{array}{lll}\text { and Cellular } & \text { Endocrinology; } & \end{array}$ http://dx.doi.org/10.1016/j.mce.2006.06.003

KNAPIK-KORDECKA M., PIWOWAR A., ŻURAWSKA-PŁAKSEJ E. WARWAS M., 2008. Albumina modyfikowana niedokrwieniem- specyficzny marker w diagnostyce kardiologicznej?, Wiadomości Lekarskie, LXI, 10-12. MILLER A, JĘDRZEJCZAK W., 2001. ALBUMINA - FUNKCJE BIOLOGICZNE I ZNACZENIE KLINICZNE. POST HIG; 55: 17-36.

MUSTAFA A., KAMAL- ELDIN A., PETERSSON E.V., ANDERSSON R., AMAN P., 2008. Effect of acrylamide content in fresh and stored rye crisp bread. J. Food Comp.Anal., 21:351-355. http://dx.doi.org/10.1016/j.jfca.2008.01.003 PETERS JT., 1996. All about albumin: Biochemistry, genetics and medical applications. Academic Press San Diego, CA.

RICE J.M. 2005. The carcinogenicity of acrylamide. Mutation Research., 580:3 20.

SHENG, Q., ZOU, H., LÜ, Z., ZOU, F., PARK, Y., YAN, Y. I WSP., 2009. Effects of acrylamide on the activity and structure of human brain creatine kinase. Int. J. Mol. Sci., 10: 4210-4222. http://dx.doi.org/10.3390/ijms10104210 SZCZERBINA T., BANACH Z., TYLKO G., PYZA E., 2008. Toxic effects of acrylamide on survival, development and haemocytes of Musca domestica, Food and Chemical Toxicology, 46:2316-2319. http://dx.doi.org/10.1016/j.fct.2008.02.019

TAREKE E, RYDBERG P, KARLSSON P, ERIKSSON S, TÖRNQVIST M. 2002. Analysis of acrylamide, a carcinogen formed in heated foodstuffs. Journal of Agricultural and Food Chemistry. 50(17):4998-5006 http://dx.doi.org/10.1021/jf020302f 